\title{
Packaging properties and control of Listeria monocytogenes in bologna by cellulosic films incorporated with pediocin
}

\author{
Propriedades da embalagem e controle de L. monocytogenes \\ em mortadela por filmes celulósicos incorporados com pediocina
}

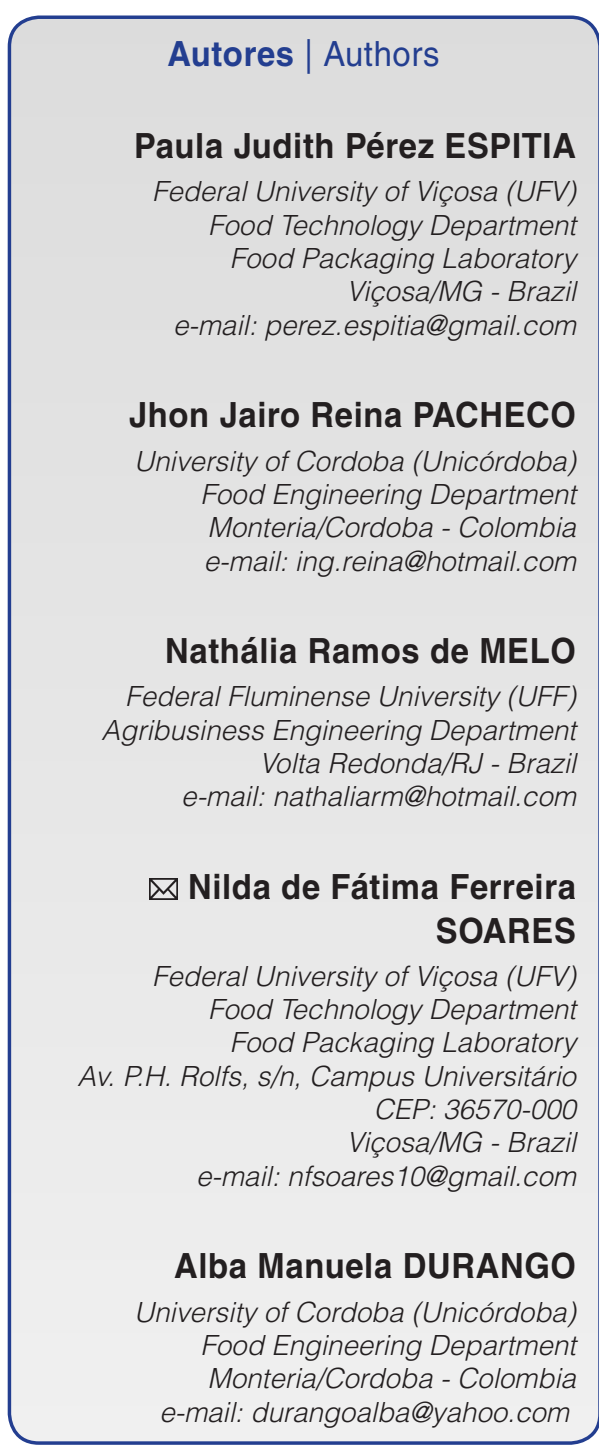

$\triangle$ Autor Correspondente / Corresponding Author

Recebido / Received: 19/02/2013

Aprovado / Approved: 29/08/2013

Publicado / Published: set./2013

\section{Summary}

Listeria monocytogenes is a foodborne pathogen, able to survive and proliferate at refrigeration temperatures. As a result, ready-to-eat meat products have been associated with major outbreaks. Producing meat products involves lethal preservation treatments, e.g. thermal treatments. Listeria contamination, however, may be introduced when products are sliced and packaged at retail businesses or delicatessens. In Brazil, sliced bologna is very popular at retail markets. After slicing, however, bologna has a short shelf-life. The aim of this work was to study the effects of pediocin incorporation on the load at break, water vapor permeability rate and structure, by microscopic analysis, of antimicrobial cellulosic packaging. The potential application of the developed packaging for the preservation of bologna and inhibition of Listeria biofilm formation was also studied. Cellulosic antimicrobial packaging films were produced with cellulose acetate and acetone. Pediocin (commercially available concentrate ALTA ${ }^{\text {TM }}$ 2341) was incorporated at 30,40 and $50 \% \mathrm{w} / \mathrm{w}$. The load at break of films was studied using the Universal Testing Machine (Instron) at $10^{\circ} \mathrm{C}$ and $25^{\circ} \mathrm{C}$. The water vapor permeability was determined by gravimetric method. A scanning electron microscope was used to study the developed packaging structure. Antimicrobial activity of films against Listeria innoucua and L. monocytogenes was tested both in vitro and in bologna samples. Results showed that values of load at break decreased with increasing concentrations of pediocin at $10{ }^{\circ} \mathrm{C}$ and 25 ${ }^{\circ} \mathrm{C}$. Regarding water vapor permeability, only the control and $50 \%$ pediocin films presented statistical difference, with the $50 \%$ pediocin film being more permeable. In vitro tests showed antimicrobial activity against $L$. innocua. Cellulosic film with $50 \%$ pediocin reduced $L$. monocytogenes growth on sliced bologna by 1.2 log cycles after 9 days and prevented biofilm formation on packaging and bologna surfaces. Hence, active cellulosic films made with $50 \%$ pediocin in the form of commercially available concentrated ALTATM 2341 have the potential of being used in a system of hurdle technologies as a final obstacle for L. monocytogenes control in bologna preservation.

Key words: Pediocin; Active packaging; Load at break; Water vapor permeability; Antimicrobial activity; Listeria sp. 


\section{Resumo}

Listeria monocytogenes é um agente patogênico veiculado por alimentos, capaz de sobreviver e proliferar em temperaturas de refrigeração. Como resultado, os produtos cárneos, prontos para consumo, têm sido associados a graves surtos mortais. A elaboração de produtos cárneos envolve tratamentos letais de conservação, como o tratamento térmico. Entretanto, a contaminação por Listeria pode ser causada quando o produto é fatiado e embalado em estabelecimentos de varejo ou em operações de delicatessen. No Brasil, a comercialização de mortadela fatiada é muito popular. Entretanto, a vida de prateleira da mortadela, após ser fatiada no mercado varejista, é curta. Este trabalho objetivou o estudo do efeito da incorporação de pediocina na carga na ruptura e na permeabilidade ao vapor de água, e da estrutura, por análise microscópica, das embalagens celulósicas antimicrobianas. Também foi estudada a aplicação potencial das embalagens desenvolvidas na preservação de mortadela e a inibição de biofilmes de Listeria. Os filmes celulósicos foram produzidos com acetato de celulose e acetona. A pediocina foi usada na forma do concentrado comercialmente disponível ALTATM 2341, incorporado a 30, 40 e 50 \% p/p. Foi estudada a carga na ruptura dos filmes usando a Máquina Universal de Ensaio de Materiais (Instron) a $10^{\circ} \mathrm{C}$ e $25^{\circ} \mathrm{C}$, e a permeabilidade ao vapor de água (PVA), determinada pelo método gravimétrico. Para estudar a estrutura dos filmes desenvolvidos, foi usado o microscópio eletrônico de varredura. A atividade antimicrobiana dos filmes contra Listeria innocua e Listeria monocytogenes foi testada por análise in vitro e em mortadela, respectivamente. Os resultados mostraram que a carga na ruptura diminuiu com altas concentrações de pediocina a $10^{\circ} \mathrm{C}$ e $25^{\circ} \mathrm{C}$. Com relação à PVA, só o filme controle e o filme com $50 \%$ de pediocina apresentaram diferença estatística, sendo mais permeável o filme com $50 \%$ de pediocina. Os testes in vitro mostraram a atividade antimicrobiana contra $L$. innocua. Os filmes celulósicos com $50 \%$ de pediocina reduziram o crescimento de L. monocytogenes na mortadela fatiada em 1,2 ciclo log após nove dias, evitando a formação de biofilmes na superfície da embalagem e da mortadela. Portanto, os filmes celulósicos ativos com $50 \%$ pediocina, na forma do concentrado comercial ALTA $^{\text {TM }}$ 2341, têm potencial para serem usados em um sistema de tecnologia de barreiras como um obstáculo final para o controle de L. monocytogenes, na conservação de mortadela.

Palavras-chave: Pediocina; Embalagens ativas; Carga na ruptura: Permeabilidade ao vapor de água; Atividade antimicrobiana; Listeria sp. 


\section{Introduction}

Listeriosis is a serious infection usually caused by ingestion of food contaminated with Listeria monocytogenes. The disease primarily affects older adults, pregnant women, newborns, and adults with weakened immune systems. On rare occasions people without these risk factors may also be affected (CDC, 2013).

Recently, the Centers for Disease Control and Prevention (CDC, 2013) estimated that approximately 1,600 illnesses and 260 deaths occur annually in the United States due to listeriosis (SCALLAN et al., 2011). Moreover, in 2010, 1,601 confirmed cases of listeriosis were reported in Europe, $17 \%$ of which were fatal, with the highest rates of infection observed in Finland, Denmark and Spain (EFSA, 2012). In Brazil, listeriosis outbreaks are not well documented and information is lacking regarding foodborne illnesses (MONTEIRO et al., 2013). However, in Brazil, a few studies have indicated the presence of $L$. monocytogenes in foods, including meat products (ROSSI et al., 2011). Listeria spp. was reported in raw meat used to make meat products, such as Brazilian sausage, and L. monocytogenes was isolated in $16.6 \%$ of the final product (SILVA et al., 2004)

Different foods have been implicated in isolated cases of listeriosis outbreaks, nevertheless, some types of food products are considered to be more susceptible to $L$. monocytogenes contamination, such as ready-to-eat and refrigerated food products (MARTINS and GERMANO, 2011).

Listeria monocytogenes is Gram-positive facultative foodborne pathogen found in food and widely distributed in nature. This microorganism is able to survive in temperatures from below freezing $\left(-7^{\circ} \mathrm{C}\right)$ to body temperature, with optimal growth at temperatures from $-18^{\circ} \mathrm{C}$ to $10^{\circ} \mathrm{C}$, which includes refrigeration temperatures. As a result, Listeria may be transmitted in readyto-eat foods that have been kept properly refrigerated (RAMASWAMY et al., 2007). Moreover, L. monocytogenes can grow in environments with $\mathrm{pH}$ values between 4.6 and 9.5 and with a water activity as low as 0.92 . This microorganism responds and survives to low-pH environments in acidic foods and during gastric passage due to a number of stress adaptation mechanisms (GANDHI and CHIKINDAS, 2007).

Since $L$. monocytogenes is able to survive and proliferate under refrigeration temperatures, ready-to-eat meat products have been associated with major fatal outbreaks. Meat products may be contaminated with this pathogen through raw materials, the processing environment and at retail markets (SOFOS and GEORNARAS, 2010).
Producing meat products, including bologna, involves lethal preservation treatments, such as thermal treatments. However, contamination with L. monocytogenes may be introduced on these products when slicing and packaging at retail businesses or delicatessens, as well as during handling in foodservice. In Brazil, sliced bologna is very popular in retail markets, but afterward it has a short shelf-life of around 5 days.

On the other hand, the consumption of foods processed with chemical preservatives has led to increased consumer concern and demand for more natural and minimally processed foods. As a result, researchers have shown growing interest in natural antimicrobial agents such as bacteriocins. Bacteriocins are a heterogeneous group of bioactive peptides that kill or inhibit the growth of closely related microorganisms, such as food pathogens (FADDA et al., 2010).

Pediocin is a widely studied bacteriocin and it is an attractive option as an antimicrobial agent due to its ability to control Listeria monocytogenes, a foodborne pathogen of special concern in the food industry (ENNAHAR et al., 2000). In the food industry, pediocin is considered to be nontoxic and without adverse effects. The bacterial strains used for pediocin production belong to the genus Pediococcus, which is a group of Gram-positive, homofermentative, lactic acid bacteria (LAB) used in the fermentation of vegetables, meats and meat products. The main bacterial strains producing pediocin are $P$. acidilactici, $P$. pentosaceus and $P$. damnosus (AMMOR and MAYO, 2007; GARDNER et al., 2001).

Antimicrobial activity of pediocin against L. monocytogenes has been reported. The inoculation of dry-fermented sausages and frankfurters with pediocin producer strains resulted in an inhibitory effect against L. monocytogenes (FOEGEDING et al., 1992; NIETOLOZANO et al., 2010). Moreover, pediocin dropwise distributed on the surface of cooked sausage slices decreased the number of $L$. monocytogenes from the initial level of $2.7 \log \mathrm{CFU} \cdot \mathrm{g}^{-1}$ sausage to $<2 \log \mathrm{CFU} \cdot \mathrm{g}^{-1}$ over 6 days (MATTILA et al., 2003).

However, depending on the characteristics of the food intended for preservation, the direct application of pediocin into the food matrix has several limitations regarding its preservation activity. As an alternative, peptides can be incorporated into packaging materials to create antimicrobial food packaging.

Antimicrobial packaging is a type of active packaging that goes beyond the traditional passive packaging role of protecting and marketing a food product. It interacts with the food in a desirable way to reduce or inhibit microorganism growth on food surfaces (SOARES et al., 2009). Antimicrobial packaging can take different forms, including: the addition of sachets or pads, containing volatile antimicrobials, into packages; 
the incorporation of antimicrobial agents directly into polymers; antimicrobial coatings on polymer surfaces and the immobilization of antimicrobials to polymers by ion or covalent bonds (APPENDINI and HOTCHKISS, 2002). Moreover, active packaging can be developed with antimicrobial peptides by three main methods of incorporation: direct peptide incorporation in the polymer; peptide coating on the polymeric surface and peptide immobilization in the polymer (ESPITIA et al., 2012).

The antimicrobial activity of polymeric matrices incorporated with peptides, especially bacteriocins, has been widely studied. However, few studies address the effects of peptides on the packaging properties and performance of packaging materials. Thus, structural analysis and measurement of packaging properties should be done to elucidate how the incorporation of antimicrobial agents, such as pediocin, relates to the primary functions of food packaging.

The knowledge of packaging mechanical performance is essential for packaging. Microscopic analysis is essential for studying the structure of food packaging and is related to the physical integrity characteristics of the developed packaging material (ESPITIA et al., 2011). Moreover, the evaluation of the water vapor barrier is also necessary because many food products are susceptible to humidity (OLIVEIRA et al., 1996).

Therefore, the aim of this work was to study the effects of pediocin incorporation on the load at break, water vapor permeability and structure, by microscopic analysis, of antimicrobial cellulosic packaging. The potential application of antimicrobial cellulosic packaging on the preservation of bologna and inhibition of Listeria biofilm formation was also studied.

\section{Material and methods}

\subsection{Production of antimicrobial cellulosic packaging}

Antimicrobial cellulosic packaging films were produced with cellulose acetate resin (Rhodia, Freiburg, Germany) and acetone P. A. (Isofar, RJ, Brazil).

The pediocin used was the commercially available concentrated ALTA 2341 (Kerry Bioscience, Ireland). This product is a fermented powder containing excipients, such as skim milk, whey and dextrose, and the bacteriocin, which is obtained by a food grade fermentation process using lactic acid cultures (Pediococcus acidilactic). The content of pediocin in this commercial product is below $50 \% \mathrm{w} / \mathrm{w}$. Thus, this information was considered when selecting the concentration of the commercially available concentrated ALTA ${ }^{\mathrm{TM}} 2341$ for incorporation in the polymeric matrix $(30,40$ and $50 \% \mathrm{w} / \mathrm{w})$, in order to obtain similar results to those observed when used pediocin directly in food products.

Antimicrobial cellulosic packaging was produced by casting method (SOARES and HOTCHKISS, 1998) with modifications as follows: the cellulosic resin was mixed with acetone to make a film-forming solution. The ratio of cellulose acetate to acetone was 1:10 (w/v).

After solubilization, pediocin in the form of commercially available concentrated ALTATM 2341 was incorporated in the cellulosic film-forming solution at concentrations of 30,40 and $50 \%$ (w/w), being pediocin concentration based on the dry weight of cellulosic resin. A control film was produced with cellulosic resin and no pediocin. The film-forming solution was spread on glass slides and left to dry at $24 \pm 1{ }^{\circ} \mathrm{C}$ until the solvent had completely evaporated. All treatments were done in the same manner.

\subsection{Mechanical and barrier properties}

The thickness of antimicrobial cellulosic packaging was measured in random areas using a micrometer (Mitutoyo Sul Americana, Suzano, SP, Brazil) and specimens were submitted to mechanical tests to evaluate the load at break according to American Society for Testing and Materials (ASTM, 2012) using the Universal Testing Machine (Instron model 3367, Norwood, MA, USA). Mechanical tests at low temperature $\left(10^{\circ} \mathrm{C}\right)$ were done placing the specimen in the environmental chamber of the Universal Testing Machine (Instron).

Ten specimens of each treatment $(15 \mathrm{~cm} \times 3 \mathrm{~cm})$ were tested. The machine was operated with a load of $1 \mathrm{kN}$ and traction speed of $50 \mathrm{~mm} / \mathrm{min}$. Mechanical tests were done at $10{ }^{\circ} \mathrm{C}$ and $25^{\circ} \mathrm{C}$ and the relative humidity was $60 \%$. The effect of temperature on the mechanical properties of the developed active cellulosic packaging was studied.

The barrier property of water vapor permeability (WVP) of the antimicrobial cellulosic films was determined by gravimetric method according to American Society for Testing and Materials (ASTM, 2010) with $75 \% \mathrm{RH}$ at room temperature $\left(24 \pm 1^{\circ} \mathrm{C}\right)$.

WVP was calculated using the following equation (Equation 1):

$\mathrm{WVP}=\left(\frac{w}{t}\right) \cdot\left(\frac{x}{\Delta \mathrm{P} \cdot \mathrm{A}}\right)$

where: $w$ = weight change due to absorbed water $(\mathrm{g})$; $t=$ time (day); $x=$ film thickness $(\mathrm{mm}) ; A=$ exposed film area $\left(m^{2}\right) ; \Delta P=$ partial pressure difference through the film.

$\Delta P$ was calculated using the following equation (Equation 2):

$\Delta P=S \cdot\left(R_{1}-R_{2}\right)$ 
where: $\mathrm{S}=$ saturated vapor pressure at $25^{\circ} \mathrm{C}(3166 \mathrm{kPa})$; $R_{1}=$ relative humidity in the desiccator $(0.75)$, expressed in fractions; $R_{2}=$ relative humidity in the interior of the cell (0.0), expressed in fractions.

\subsection{Microscopic analysis}

Microscopic analysis of the antimicrobial cellulosic packaging was made at the Microscopy and Microanalysis Center at the Federal University of Viçosa. A Scanning Electron Microscope (SEM - LEO Electron, Cambridge, England) was used to monitor the surface of the developed antimicrobial cellulosic films. The SEM was used with an acceleration voltage of $10-15 \mathrm{kV}$ and a working distance of $12 \mathrm{~mm}$. The samples $\left(0.5 \mathrm{~cm}^{2}\right)$ were fastened in stubs and covered with a gold layer (20 nm thick) in the metallizer SCD 010 (Balzer Union, Furstentum, Lichtenstein). Samples were put into holders for SEM examination and microphotography capture.

\subsection{In vitro antimicrobial activity}

Antimicrobial activity in vitro of each active cellulosic packaging was evaluated against Listeria innocua (ATCC 33090) (Fundação Osvaldo Cruz, Rio de Janeiro, RJ, Brazil). Pure culture, previously transferred twice to $10 \mathrm{~mL}$ of TSB (Acumedia, USA) at $35 \pm 1^{\circ} \mathrm{C}$, was inoculated on Oxford media (DifCo ${ }^{\mathrm{TM}}$ Sparks, NV, USA) and disks of each film (diameter: $10 \mathrm{~mm}$ ) were placed in the center of Petri dishes. Petri dishes were sealed and incubated at $35 \pm 1{ }^{\circ} \mathrm{C}$ for $24 \mathrm{~h}$. Afterward, the inhibition zone of each treatment was measured with a ruler in three transversal directions to determine the mean diameter.

\subsection{Antimicrobial activity in bologna}

In order to test the antimicrobial activity of antimicrobial cellulosic films in food, bologna obtained in the local market (Viçosa, Brazil) was placed in contact with the active cellulosic packaging.

The inoculation of bologna with L. monocytogenes was done according to methodology proposed by Santiago-Silva et al. (2009) with modifications. Bologna slices were immersed in a $0.1 \%$ peptone solution with a suspension of L. monocytogenes (ATCC 15313) at a concentration of approximately $10^{3} \mathrm{CFU} \cdot \mathrm{mL}^{-1}$. Afterward, bologna slices were placed in contact with a suspension of L. monocytogenes (ATCC 15313) at a concentration of $10^{3}$ CFU. $\mathrm{mL}^{-1}$ and covered with active cellulosic packaging.

The antimicrobial cellulosic films were intercalated with bologna slices, and these systems were placed in polystyrene expanded (PS) trays wrapped with PVC film, as in the local market. The system "bologna - antimicrobial cellulosic films" was then refrigerated at $10 \pm 2{ }^{\circ} \mathrm{C}$, similar to abusive temperatures that can occur at local markets. The bologna and the films were microbiologically analyzed and colonies counts of $L$. monocytogenes were determined at 0, 3, 6 and 9 days of storage. The systems were microbiologically analyzed according to Downes and Ito (2001).

Samples of the antimicrobial cellulosic films in contact with the food were analyzed by means of SEM to study the interaction between L. monocytogenes and developed films.

\subsection{Statistical analysis}

The results were subjected to analysis of variance (ANOVA) and Tukey test (5\% significance) using the Statistical Analysis System software (SAS Institute Inc.). Statistical analysis of regression was used when recommended.

\section{Results and discussion}

\subsection{Mechanical and barrier properties}

Results showed significant differences concerning film thickness $(p<0.05)$. Antimicrobial cellulosic films incorporated with a high concentration of pediocin showed greater thickness (Table 1). Some researchers have shown that, when there is a strong interaction between the polymeric matrix and antimicrobial, the film thickness is affected, thereby altering the polymeric structure and consequently their mechanical performance (CAMILLOTO et al., 2009; GOUNGA et al., 2007).

Load at break of tested films presented significant differences $(p<0.05)$ among treatments at temperatures of $10^{\circ} \mathrm{C}$ and $25^{\circ} \mathrm{C}$ (Figure 1).

Antimicrobial cellulosic packaging incorporated with $40 \%$ pediocin presented the lowest load at break $(22.6 \mathrm{~N})$ at $10{ }^{\circ} \mathrm{C}$, while film incorporated with $30 \%$, as well as the control film, presented the highest value $(38 \mathrm{~N})$ at this temperature.

At $25^{\circ} \mathrm{C}$ the antimicrobial cellulosic packaging presented higher values of load at break compared to the values obtained at $10{ }^{\circ} \mathrm{C}$. The film incorporated with $30 \%$ pediocin presented the highest value of load at break $(79.7 \mathrm{~N})$, while the film incorporated at $50 \%$ presented the lowest value $(49.7 \mathrm{~N})$.

Table 1. Thickness of control film and antimicrobial cellulosic films incorporated with different concentrations of pediocin ALTA $^{\text {TM }} 2341$ at $24 \pm 1{ }^{\circ} \mathrm{C}$

\begin{tabular}{ccccc} 
Measured & \multicolumn{4}{c}{ Pediocin concentration } \\
parameter & Control & $\mathbf{3 0} / \mathrm{w})$ & $\mathbf{4 0}$ & $\mathbf{5 0}$ \\
\hline $\begin{array}{c}\text { Thickness } \\
(\mathrm{mm})\end{array}$ & $0.07 \pm 0.02^{\mathrm{d}}$ & $0.14 \pm 0.03^{\mathrm{c}}$ & $0.21 \pm 0.01^{\mathrm{b}}$ & $0.23 \pm 0.01^{\mathrm{a}}$ \\
\hline
\end{tabular}

*Values are means of five measurements. Mean values bearing the same letter are not significantly different $(p>0.05)$. 


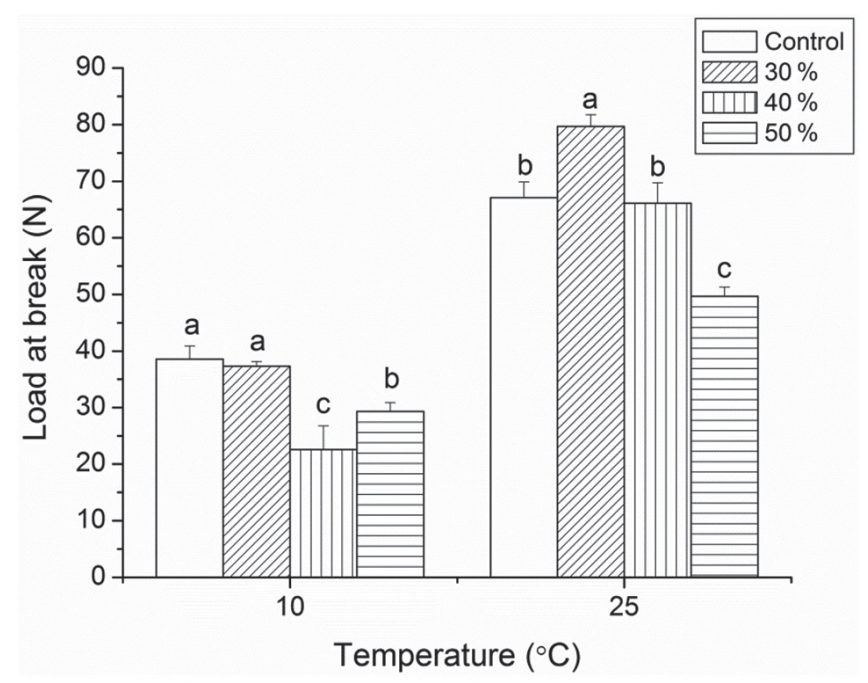

Figure 1. Effect of temperature on load at break of control film and antimicrobial cellulosic films incorporated with 30, 40 and $50 \% \mathrm{w} / \mathrm{w}$ of pediocin in the form of the commercially available concentrated ALTA $^{\mathrm{TM}} 2341$.

High values of load at break represent high film resistance to the rupture. As such, higher film resistance was observed with antimicrobial cellulosic packaging incorporated with $30 \%$ pediocin at temperatures of 10 and $25{ }^{\circ} \mathrm{C}$. Above $30 \%$ pediocin concentration, the packaging material presented diminished mechanical resistance to rupture.

This may be due to the presence of large peptide crystals. Thus, the interaction between an excessive amount of pediocin crystals and cellulosic chains lead to the weakening of the polymeric structure and decreased the resistance of the polymeric matrix.

These results are in agreement with previous work at $25{ }^{\circ} \mathrm{C}$, in which the addition of pediocin in concentrations of $25 \%$ increased the force required for film rupture in relation to control, indicating a possible interaction between the pediocin and the cellulosic matrix, resulting in a more rigid structure (SANTIAGO-SILVA et al., 2009). However, at higher concentrations, such as $50 \%$ pediocin, the packaging material may have had an excess of incorporated pediocin, which weakened the cellulosic chains.

Moreover, the WVP of cellulosic films incorporated with pediocin presented significant differences between the control film and the $50 \% \mathrm{w} / \mathrm{w}$ concentration $(p<0.05)$. In this way, the film incorporated with $50 \%$ pediocin presented the highest value of WVP (Table 2), while the control film had the lowest WPV, although the WVP of the control film was not statistically different compared to films with 30 and $40 \%$ pediocin.
Table 2. Water vapor permeability (WVP) of control film and antimicrobial cellulosic films incorporated with different concentrations of pediocin ALTA ${ }^{\mathrm{TM}} 2341$ at $24 \pm 1{ }^{\circ} \mathrm{C}$.

\begin{tabular}{ccccc}
$\begin{array}{c}\text { Measured } \\
\text { parameter }\end{array}$ & \multicolumn{4}{c}{ Pediocin concentration* $(\% \mathbf{w} / \mathbf{w})$} \\
$\begin{array}{c}\text { WVTR } \\
\left(\mathrm{g} \cdot \mathrm{m}^{-2} \cdot \mathrm{day}^{-1}\right)\end{array}$ & $0.0116^{\mathrm{b}}$ & $0.0193^{\mathrm{ab}}$ & $0.0221^{\mathrm{ab}}$ & $0.0245^{\mathrm{a}}$ \\
\hline $\begin{array}{l}{ }^{*} \text { Mean values bearing the same letter are not significantly different } \\
(\mathrm{p}>0.05) .\end{array}$
\end{tabular}

\subsection{Microscopic analysis}

SEM analyses revealed the presence of dispersed cellulosic agglomerates on the surface of control film (Figure 2). These cellulosic agglomerates presented larger size, in the order of micrometer, but were reduced in number. We attribute this to the incomplete solubility of the cellulosic acetate in acetone.

Peptide crystals were observed in the microphotography of antimicrobial cellulosic films with $50 \%$ pediocin (Figure 3). These results indicated that a heterogeneous distribution of the peptide occurred in the cellulosic matrix when compared to the control.

\subsection{In vitro antimicrobial activity}

All the antimicrobial cellulosic film showed activity against $L$. innocua (Figure 4). Films incorporated with $50 \%$ pediocin had the largest inhibition zone $(19 \mathrm{~mm})$, while films incorporated with 40 and $30 \%$ of pediocin had diameters of 17 and $16 \mathrm{~mm}$, respectively.

Antimicrobial peptides are relatively resistant to heat (APPENDINI and HOTCHKISS, 2001). However, they have greater antimicrobial activity when heat is not used in the incorporation process. Thus, studies on the incorporation of antimicrobial peptides directly in the polymeric material, especially bacteriocins, and their antimicrobial activity after incorporation process are of great interest (ESPITIA et al., 2012).

In this work, the antimicrobial activity of pediocin was retained after its incorporation in the cellulosic matrix. Also, the antimicrobial activity of pediocin was affected by the concentration.

\subsection{Antimicrobial activity in bologna}

Considering the in vitro test results, antimicrobial cellulosic film incorporated with $50 \%$ pediocin was selected to test the potential application as antimicrobial food packaging.

Previous studies have shown that much higher concentration of antimicrobials, such as essential oils and organic acids, is required in foods to obtain similar antimicrobial activity, as observed in tests done in vitro 


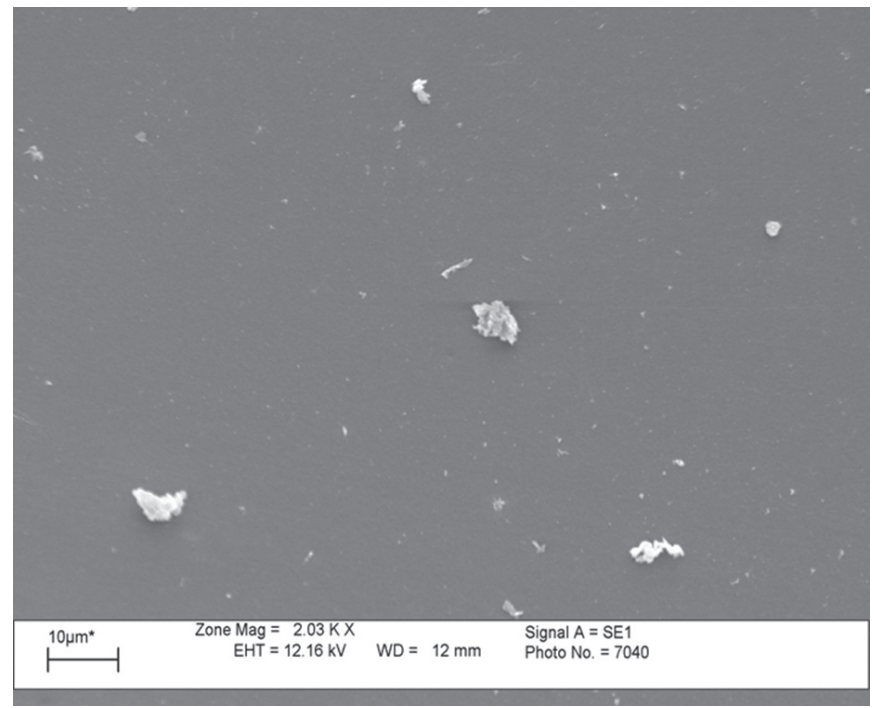

Figure 2. Microphotograph of the upper surface of control film (without pediocin).

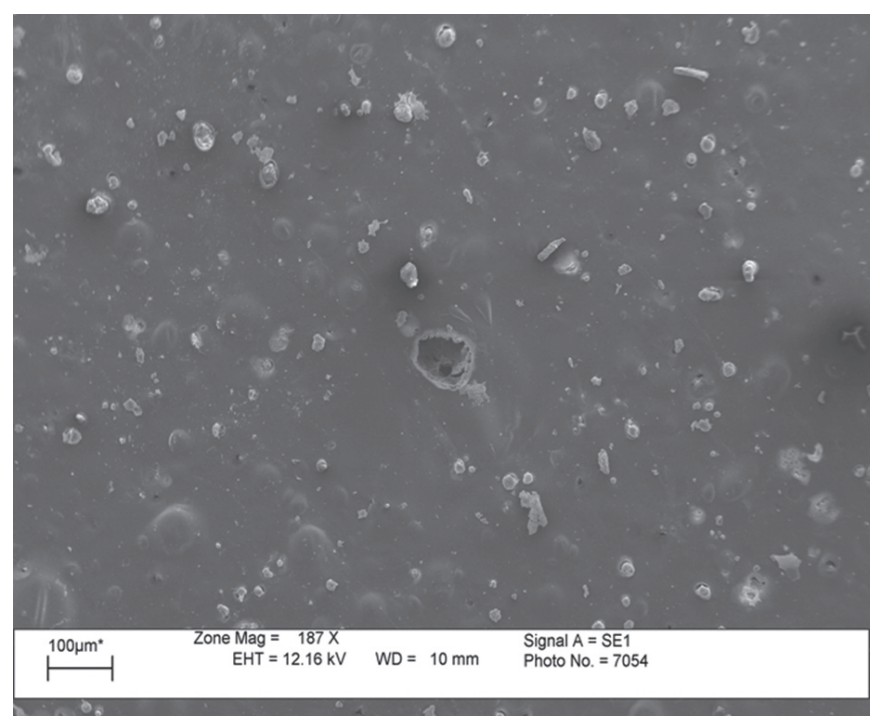

Figure 3. Microphotograph of the upper surface of antimicrobial cellulosic film incorporated with $50 \%$ pediocin.

using culture media (BURT, 2004; MURIEL-GALET et al., 2012).

In this way, the levels of antimicrobials and their active components necessary for inhibiting microbial growth are higher in foods than in culture media due to interactions between antimicrobial and the food matrix (TZORTZAKIS and ECONOMAKIS, 2007).

The evaluation of bologna packaged in antimicrobial cellulosic film incorporated with $50 \%$ of pediocin, after 9 days of storage at $10^{\circ} \mathrm{C}$, showed that $L$. monocytogenes had a growth of 1.2 log CFU.g ${ }^{-1}$ less than in the control sample (Figure 5).

The hydrophobic nature of antimicrobial peptides is important because it eases the interaction between pediocin crystals and the target microorganism. Peptide

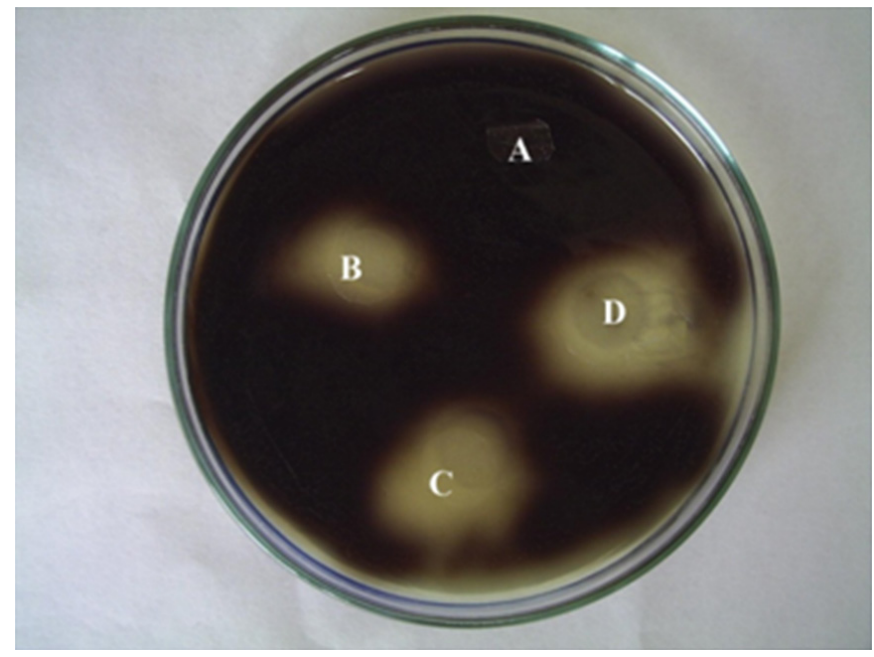

Figure 4. Control film (A) and antimicrobial activity of developed films incorporated with $30 \%(B), 40 \%(C)$ and $50 \%$ (D) pediocin.

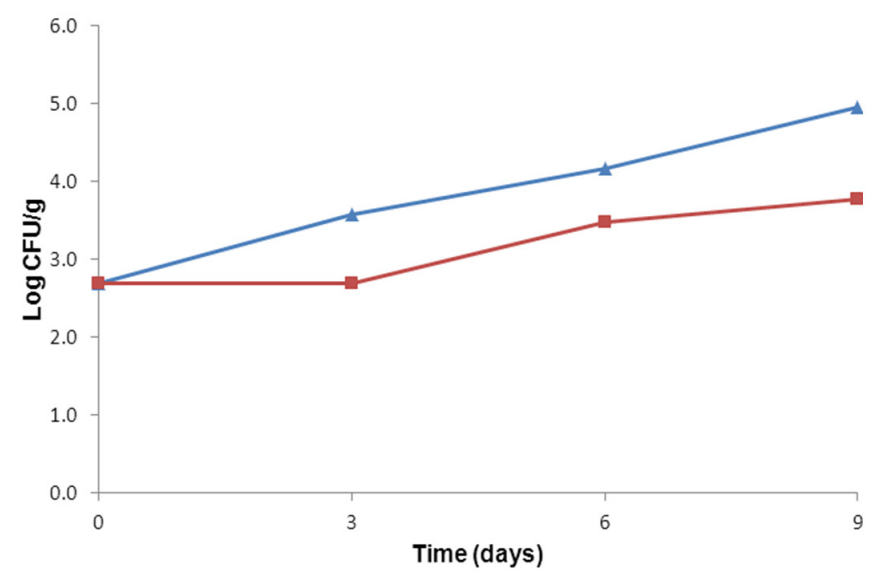

Figure 5. Antimicrobial activity of developed films against L. monocytogenes in bologna. Control film ( $\mathbf{\Delta})$ and film incorporated with $50 \%$ pediocin (-).

hydrophobicity is a factor required for insertion into the membrane, allowing the peptide to interact with the microbial membrane and consequently exerting antimicrobial activity (JENSSEN et al., 2006).

Our results agree with previous studies. For example, cheddar cheese prepared with Lactococcus lactis subsp. lactis MM217, a starter culture containing genes coding for pediocin production and stored at $8{ }^{\circ} \mathrm{C}$, showed a reduction of 2 log CFU. $g^{-1}$ after one week of ripening and 1 log CFU. $g^{-1}$ after three months (BUYONG et al., 1998); refrigerated chickens at $5{ }^{\circ} \mathrm{C}$ treated with a pediocin-cell preparation from Pediococcus acidilactici $\mathrm{H}$ showed a reduction of 1 log CFU.g ${ }^{-1}$ at day 0 , and from day 7 to 28 the counting were reduced below detectable levels (GOFF et al., 1996); and vacuum- 
Packaging properties and control of Listeria monocytogenes in bologna by cellulosic films incorporated with pediocin ESPITIA, P. J. P. et al.

packaged beef franks stored at $4{ }^{\circ} \mathrm{C}$ showed a reduction of 1 log CFU.g $g^{-1}$ when treated with pediocin and sodium acetate after two weeks of storage and about 1 to 2 log CFU.g ${ }^{-1}$ after three weeks (UHART et al., 2004).

Also, microbiological analysis of films revealed that the surface of antimicrobial cellulosic packaging with $50 \%$ pediocin showed a L. monocytogenes count of 0.9 log less than the control film on the $9^{\text {th }}$ day of analysis (Figure 6). This result indicates that the developed film inhibited the Listeria biofilm on the surface of the active material and therefore on the contaminated surface of bologna.

These results are confirmed by SEM analyses, which showed biofilm formation of $L$. monocytogenes on the surface of the control film (Figure 7A), as well as the presence of sessile cells. On the other hand, the surface of the cellulosic active packaging with $50 \%$ pediocin presented limited bacterial growth and individual sessile cells of L. monocytogenes (Figure 7B).

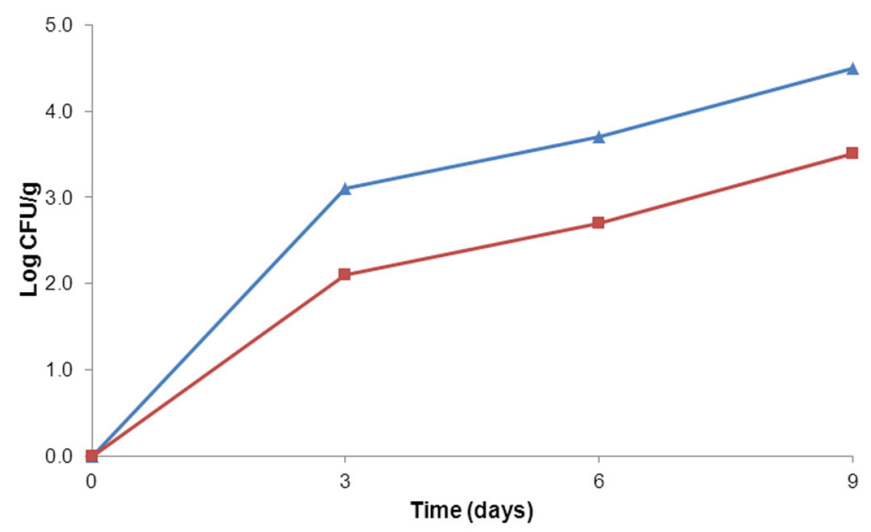

Figure 6. Growth of L. monocytogenes on the control film surface $(\boldsymbol{\Delta})$ and film incorporated with $50 \%$ pediocin ( $\mathbf{a}$ ) in contact with bologna.
The presence of few bacterial cells indicated that pediocin interacted with the microorganism, leading to the inhibition of $L$. monocytogenes. The mechanism of action of antimicrobial peptides is based on direct contact with microorganisms and their ability to form pores in microbial membrane surface (GARCíA et al., 2010). This results in the total or partial dissipation of the proton motive force, ultimately causing cellular death.

Therefore, the developed antimicrobial cellulosic film can be used as part of a hurdle technology in the food industry to control the growth of $L$. monocytogenes to achieve greater microbiologic safety in food preservation.

\section{Conclusions}

The incorporation of pediocin in the form of the concentrated product ALTA ${ }^{\text {TM }} 2341$ resulted in changes in the mechanical resistance at $10{ }^{\circ} \mathrm{C}$ and $25^{\circ} \mathrm{C}$ of developed films. The WVP of films was also affected as a result of pediocin incorporation, with the film incorporated with $50 \%$ pediocin presenting the highest value of WVP. Moreover, microscopic analysis showed differences on the surface of control and active films as a result of pediocin incorporation.

The antimicrobial cellulosic films incorporated with $50 \%$ pediocin showed the highest antilisterial activity in vitro and the study with bologna confirmed the in vitro assay, since this presented a reduction of $1.2 \mathrm{log}$ CFU. $g^{-1}$ for L. monocytogenes. In addition, microbiological analysis showed that the developed antimicrobial cellulosic films inhibited Listeria biofilm on the surface of the active material and therefore on the contaminated surface of bologna.

Therefore, the antimicrobial cellulosic film with $50 \%$ pediocin in the form of commercially available ALTATM

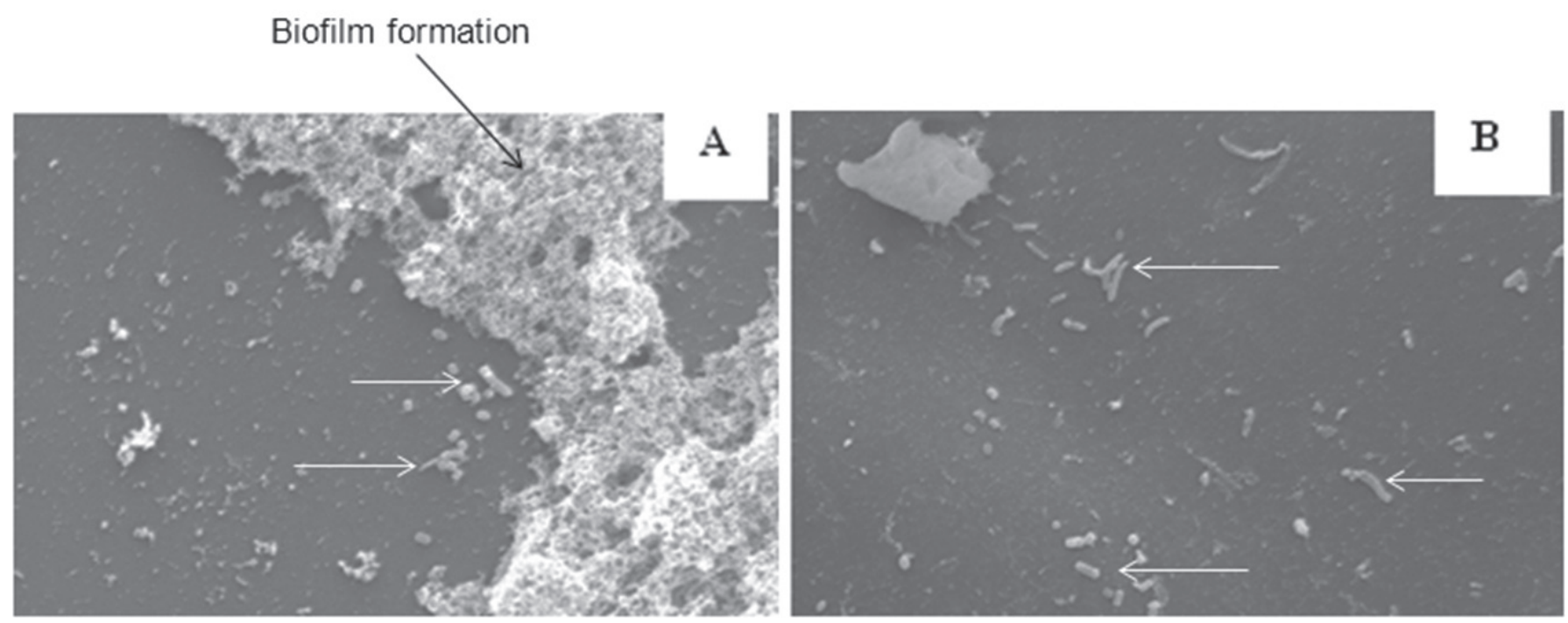

Figure 7. Growth of L. monocytogenes on the surface of control film (A) and antimicrobial packaging (B) in contact with bologna (white arrows show sessile cells). 
Packaging properties and control of Listeria monocytogenes in bologna by cellulosic films incorporated with pediocin ESPITIA, P. J. P. et al.

2341 can be used in a system of hurdle technologies as a final obstacle to the growth of L. monocytogenes, a pathogenic microorganism, in order to improve the food safety and shelf-life of meat products, since pathogenic contamination of these products usually begins with microbial growth on the product surface.

\section{Acknowledgments}

The authors thank Journal Editors of America LLC for language and writing assistance. Financial support for this research was provided by Coordenação de Aperfeiçoamento de Pessoal de Nível Superior (CAPES) and Conselho Nacional de Desenvolvimento Científico e Tecnológico (CNPq).

\section{References}

AMERICAN SOCIETY FOR TESTING AND MATERIALS - ASTM. ASTM D882: Standard Test Method for Tensile Properties of Thin Plastic Sheeting. West Conshohocken: ASTM, 2012. 10 p.

AMERICAN SOCIETY FOR TESTING AND MATERIALS - ASTM. ASTM E96/E96M: Standard Test Methods for Water Vapor Transmission of Materials. West Conshohocken: ASTM, 2010. $11 \mathrm{p}$.

AMMOR, M. S.; MAYO, B. Selection criteria for lactic acid bacteria to be used as functional starter cultures in dry sausage production: An update. Meat Science, Amsterdam, v. 76, n. 1, p. 138-146, 2007. PMid:22064200. http://dx.doi.org/10.1016/j. meatsci.2006.10.022

APPENDINI, P.; HOTCHKISS, J. H. Review of antimicrobial food packaging. Innovative Food Science and Emerging Technologies, Amsterdam, v. 3, n. 2, p. 113-126, 2002. http:// dx.doi.org/10.1016/S1466-8564(02)00012-7

APPENDINI, P.; HOTCHKISS, J. H. Surface modification of poly(styrene) by the attachment of an antimicrobial peptide. Journal of Applied Polymer Science, Hoboken, v. 81, n. 3, p. 609-616, 2001. http://dx.doi.org/10.1002/app.1476

BURT, S. Essential oils: their antibacterial properties and potential applications in foods - a review. International Journal of Food Microbiology, Amsterdam, v. 94, n. 3, p. 223-253, 2004. PMid:15246235. http://dx.doi.org/10.1016/j. ijfoodmicro.2004.03.022

BUYONG, N.; KOK, J.; LUCHANSKY, J. B. Use of a genetically enhanced, pediocin-producing starter culture, Lactococcus lactis subsp. lactis MM217, to control Listeria monocytogenes in Cheddar cheese. Applied and Environmental Microbiology, Washington, v. 64, n. 12, p. 4842-4845, 1998.

CAMILLOTO, G. P.; SOARES, N. D. F. F.; PIRES, A. C. D. S.; PAULA, F. S. D. Preservation of sliced ham through triclosan active film. Packaging Technology and Science, Hoboken, v. 22, n. 8, p. 471-477, 2009. http://dx.doi.org/10.1002/pts.871
CENTERS FOR DISEASE CONTROL AND PREVENTION - CDC. Listeria (Listeriosis). Atlanta: Center for disease control and prevention, 2013. Disponível em: <http://www.cdc.gov/listeria/>. Accessed: 16 ago. 2013.

DOWNES, F. P.; ITO, K. Compendium of Methods for the Microbiological Examination of Foods. 4th ed. Washington: American Public Health Association, 2001. 676 p. http://dx.doi. org/10.2105/9780875531755

ENNAHAR, S.; SASHIHARA, T.; SONOMOTO, K.; ISHIZAKI, A. Class Ila bacteriocins: biosynthesis, structure and activity. FEMS Microbiology Reviews, Hoboken, v. 24, n. 1, p. 85-106, 2000. http://dx.doi.org/10.1111/j.1574-6976.2000.tb00534.x

ESPITIA, P. J. P.; SOARES, N. D. F. F.; BOTTI, L. C. M.; SILVA, W. A. Effect of essential oils in the properties of cellulosic active packaging. Macromolecular Symposia, Hoboken, v. 299-300, n. 1, p. 199-205, 2011. http://dx.doi.org/10.1002/ masy.200900124

ESPITIA, P. J. P.; SOARES, N. D. F. F.; COIMBRA, J. S. D. R.; DE ANDRADE, N. J.; CRUZ, R. S.; MEDEIROS, E. A. A. Bioactive peptides: Synthesis, properties, and applications in the packaging and preservation of food. Comprehensive Reviews in Food Science and Food Safety, New Jersey, v. 11, n. 2, p. 187-204, 2012. http://dx.doi.org/10.1111/j.15414337.2011.00179.x

EUROPEAN FOOD SAFETY AUTHORITY - EFSA. Scientific report of EFSA and ECDC: The European Union summary report on trends and sources of zoonoses, zoonotic agents and foodborne outbreaks in 2010. EFSA Journal, Parma, v. 10, n. 3, p. 2597, 2012.

FADDA, S.; LÓPEZ, C.; VIGNOLO, G. Role of lactic acid bacteria during meat conditioning and fermentation: Peptides generated as sensorial and hygienic biomarkers. Meat Science, Amsterdam, v. 86, n. 1, p. 66-79, 2010. PMid:20619799. http:// dx.doi.org/10.1016/j.meatsci.2010.04.023

FOEGEDING, P. M.; THOMAS, A. B.; PILKINGTON, D. H.; KLAENHAMMER, T. R. Enhanced control of Listeria monocytogenes by in situ-produced pediocin during dry fermented sausage production. Applied and Environmental Microbiology, Washington DC, v. 58, n. 3, p. 884-890, 1992.

GANDHI, M.; CHIKINDAS, M. L. Listeria: A foodborne pathogen that knows how to survive. International Journal of Food Microbiology, Amsterdam, v. 113, n. 1, p. 1-15, 2007. PMid:17010463. http://dx.doi.org/10.1016/j. ijfoodmicro.2006.07.008

GARCÍA, P.; RODRÍGUEZ, L.; RODRÍGUEZ, A.; MARTínEZ, B. Food biopreservation: promising strategies using bacteriocins, bacteriophages and endolysins. Trends in Food Science \& Technology, Amsterdam, v. 21, n. 8, p. 373-382, 2010. http:// dx.doi.org/10.1016/j.tifs.2010.04.010

GARDNER, N. J.; SAVARD, T.; OBERMEIER, P.; CALDWELL, G.; CHAMPAGNE, C. P. Selection and characterization of mixed starter cultures for lactic acid fermentation of carrot, cabbage, 
Packaging properties and control of Listeria monocytogenes in bologna by cellulosic films incorporated with pediocin ESPITIA, P. J. P. et al.

beet and onion vegetable mixtures. International Journal of Food Microbiology, Amsterdam, v. 64, n. 3, p. 261-275, 2001. http://dx.doi.org/10.1016/S0168-1605(00)00461-X

GOFF, J. H.; BHUNIA, A. K.; JOHNSON, M. G. Complete inhibition of low levels of Listeria monocytogenes on refrigerated chicken meat with pediocin $\mathrm{AcH}$ bound to heat-killed Pediococcus acidilactici cells. Journal of Food Protection, Des Moines, v. 59, n. 11, p. 1187-1192, 1996.

GOUNGA, M. E.; XU, S.-Y.; WANG, Z. Whey protein isolatebased edible films as affected by protein concentration, glycerol ratio and pullulan addition in film formation. Journal of Food Engineering, Amsterdam, v. 83, n. 4, p. 521-530, 2007. http:// dx.doi.org/10.1016/j.jfoodeng.2007.04.008

JENSSEN, H.; HAMILL, P.; HANCOCK, R. E. W. Peptide antimicrobial agents. Clinical Microbiology Reviews, Washington DC, v. 19, n. 3, p. 491-511, 2006. PMid:16847082 PMCid:PMC1539102. http://dx.doi.org/10.1128/CMR.00056-05

MARTINS, E. A.; GERMANO, P. M. L. Listeria monocytogenes in ready-to-eat, sliced, cooked ham and salami products, marketed in the city of São Paulo, Brazil: Occurrence, quantification, and serotyping. Food Control, Amsterdam, v. 22, n. 2, p. 297-302, 2011. http://dx.doi.org/10.1016/j.foodcont.2010.07.026

MATTILA, K.; SARIS, P.; TYÖPPÖNEN, S. Survival of Listeria monocytogenes on sliced cooked sausage after treatment with pediocin $\mathrm{AcH}$. International Journal of Food Microbiology, Amsterdam, v. 89, n. 2-3, p. 281-286, 2003. http://dx.doi. org/10.1016/S0168-1605(03)00299-X

MONTEIRO, L. R. L. D.; MESQUITA, A. J. D.; ANDRÉ, M. C. D. P. B.; CARDOSO, J. L. Molecular characterization of Listeria monocytogenes isolated from animal products in a city of Northern Brazil. Ciência Rural, Santa Maria, v. 43, n. 8, p. 14431448, 2013.

MURIEL-GALET, V.; LÓPEZ-CARBALLO, G.; GAVARA, R.; HERNÁNDEZ-MUÑOZ, P. Antimicrobial food packaging film based on the release of LAE from EVOH. International Journal of Food Microbiology, Amsterdam, v. 157, n. 2 , p. 239-244, 2012. PMid:22640726. http://dx.doi.org/10.1016/j. ijfoodmicro.2012.05.009

NIETO-LOZANO, J. C.; REGUERA-USEROS, J. I.; PELÁEZMARTÍNEZ, M. D. C.; SACRISTÁN-PÉREZ-MINAYO, G.; GUTIÉRREZ-FERNÁNDEZ, Á. J.; LA TORRE, A. H. D. The effect of the pediocin PA-1 produced by Pediococcus acidilactici against Listeria monocytogenes and Clostridium perfringens in Spanish dry-fermented sausages and frankfurters. Food Control, Amsterdam, v. 21, n. 5, p. 679-685, 2010. http://dx.doi. org/10.1016/j.foodcont.2009.10.007

OLIVEIRA, L. M.; ALVES, R. M. V.; SARANTOPOULOS, C. I. G. L.; PADULA, M.; GARCIA, E. E. C.; COLTRO, L. Ensaios para Avaliação de Embalagens Plásticas Flexíveis. Campinas: Centro de Tecnologia de Embalagem - CETEA, 1996. 267 p.

RAMASWAMY, V.; CRESENCE, V. M.; REJITHA, J. S.; LEKSHMI, M. U.; DHARSANA, K. S.; PRASAD, S. P.; VIJILA, H. M. Listeria
- review of epidemiology and pathogenesis. Journal of Microbiology, Immunology and Infection, Amsterdam, v. 40, p. 4-13, 2007.

ROSSI, L. P. R.; ALMEIDA, R. C. C.; LOPES, L. S.; FIGUEIREDO, A. C. L.; RAMOS, M. P. P.; ALMEIDA, P. F. Occurrence of Listeria spp. in Brazilian fresh sausage and control of Listeria monocytogenes using bacteriophage P100. Food Control, Amsterdam, v. 22, n. 6, p. 954-958, 2011. http://dx.doi. org/10.1016/j.foodcont.2010.12.001

SANTIAGO-SILVA, P.; SOARES, N. F. F.; NÓBREGA, J. E.; WANDERLEY JÚNIOR, M. A.; BARBOSA, K. B. F.; VOLP, A. C. P.; ZERDAS, E. R. M. A.; WÜRLITZER, N. J. Antimicrobial efficiency of film incorporated with pediocin $\left(\right.$ ALTA $^{\circledR} 2351$ ) on preservation of sliced ham. Food Control, Amsterdam, v. 20, n. 1, p. 85-89, 2009. http://dx.doi.org/10.1016/j.foodcont.2008.02.006

SCALLAN, E.; HOEKSTRA, R. M.; ANGULO, F. J.; TAUXE, R. V.; WIDDOWSON, M. A.; ROY, S. L.; JONES, J. L.; GRIFFIN, P. M. Foodborne illness acquired in the United States - major pathogens. Emerging Infectious Diseases, Atlanta, v. 17, n. 1, p. 7-15, 2011.

SILVA, W. P.; LIMA, A. S.; GANDRA, E. A.; ARAÚJO, M. R.; MACEDO, M. R. P.; DUVAL, E. H. Listeria spp. no processamento de linguiça frescal em frigoríficos de Pelotas, RS, Brasil. Ciência Rural, Santa Maria, v. 34, p. 911-916, 2004.

SOARES, N. F. F.; HOTCHKISS, J. H. Bitterness reduction in grapefruit juice through active packaging. Packaging Technology and Science, Hoboken, v. 11, n. 1, p. 9-18, 1998. http://dx.doi.org/10.1002/(SICI)1099-1522(199802)11:1<9::AIDPTS413>3.0.CO;2-D

SOARES, N. F. F.; PIRES, A. C. S.; CAMILLOTO, G. P.; SANTIAGOSILVA, P.; ESPITIA, P. J. P.; SILVA, W. A. Recent patents on active packaging for food application. Recent Patents on Food, Nutrition \& Agriculture, Sharjah, v. 1, p. 171-178, 2009.

SOFOS, J. N.; GEORNARAS, I. Overview of current meat hygiene and safety risks and summary of recent studies on biofilms, and control of Escherichia coli O157:H7 in nonintact, and Listeria monocytogenes in ready-to-eat, meat products. Meat Science, Amsterdam, v. 86, n. 1, p. 2-14, 2010. PMid:20510532. http:// dx.doi.org/10.1016/j.meatsci.2010.04.015

TZORTZAKIS, N. G.; ECONOMAKIS, C. D. Antifungal activity of lemongrass (Cympopogon citratus L.) essential oil against key postharvest pathogens. Innovative Food Science and Emerging Technologies, Amsterdam, v. 8, n. 2, p. 253-258, 2007. http://dx.doi.org/10.1016/j.ifset.2007.01.002

UHART, M.; RAVISHANKAR, S.; MAKS, N. D. Control of Listeria monocytogenes with combined antimicrobials on beef franks stored at $4{ }^{\circ} \mathrm{C}$. Journal of Food Protection, Des Moines, v. 67, n. 10, p. 2296-2301, 2004. 